\title{
BOARD DIVERSITY: MORE THAN A GENDER ISSUE?
}

\author{
Michael AdAms*
}

There has been extensive research conducted on the importance of corporate governance around the world. The research seems to demonstrate that, regardless of whether corporations are based in common law or civil code systems, their longevity and sustainability arise from good corporate governance. However, the evidence does not clearly demonstrate a correlation between a particular organisation's governance structure and practices and its share price. Around the world the question of board diversity is gaining in importance. The beginning of the debate in the 1960s centred on gender. While it is essential to conduct a debate on gender diversity, other aspects of diversity should also be considered. Race, culture and even age may have a direct impact on the performance of a board. Australian companies, particularly those listed on the ASX, have a poor record of instituting any type of diversity. The USA and European Union have a much wider range of policies to promote diversity on corporate boards. The key question is how best to regulate to promote diversity across gender, race, culture and age. The historical approach of regulating diversity by setting targets and requiring disclosure does not seem to have delivered substantial change. Is it the right time to impose mandatory requirements, or are there other alternative strategies? Without doubt change is required, but there will be opposition.

\section{INTRODUCTION}

The last two decades have seen major debates on corporate governance, based on a variety of different paradigms, mostly linked to legal frameworks, finance, accounting and economics. Board structure and composition have been particularly debated and are key measurable aspects of corporate governance practices, with correlations to financial returns, sustainability (the longevity of the corporation) and corporate social responsibility (CSR). Critical distinctions can be drawn between Australian Securities Exchange (ASX) listed companies,

\footnotetext{
* Dean, School of Law, Western Sydney University. The author wishes to thank Grace Borsellino, part-time lecturer in law at UWS, for her research assistance.
} 
public companies, private companies, not-for-profit associations and government-controlled entities. Corporate governance issues, including those arising from the structure and composition of the governing body, affect all these organisations. To mandate a particular board composition by imposing a quota of specific types of board members would be controversial in Australia. Nevertheless, pressure from a variety of stakeholders, investors, government, stock exchanges and human rights advocates, may increase the urgency of changes to board composition; progress may need to be faster than the glacial progress currently being made.

The international research on board composition in general has centred on the gender debate. However, the diversity of board membership goes far beyond the issue of gender. This article will assess the need to increase diversity - for the primary purpose of improving performance and corporate social responsibility — on all boards and in particular ASX listed company boards. Obviously, gender diversity is a key type of diversity, but it is also important to consider the importance of other aspects of diversity, such as diversity based on race and cultural heritage (expressed as 'ethnicity'), education, professional background and age, as critical factors in a board's composition. Limited empirical research has been conducted on these other aspects of diversity in corporate governance. Further research should therefore be a high priority to stimulate and inform the debate over targets and/or quotas for board membership. This article examines the role of diversity and its benefits in corporate governance, international experiences with board diversity and the impact or effectiveness of targets and quotas imposed by governments to achieve greater diversity.

\section{The Role of Corporate Governance AND ITS DEFINITIONAL HISTORY}

A large amount of academic literature has been dedicated to the formal definition of corporate governance. One of the issues has been whether to accept that different disciplines have different definitions of corporate governance, so that the agreed concepts in the legal field can be distinguished from those applying in the fields of economics, finance, accounting, and management theory. Even the history of corporate governance is disputed. Early references to the $13^{\text {th }}$ century Swiss Cantons ${ }^{1}$ use the term expressly, as does the more contemporary Sir Adrian Cadbury in the landmark Cadbury

\footnotetext{
${ }^{1}$ Michael Adams, 'The Convergence of International Corporate Governance Systems - Where is Australia Heading?'(2002) 54(1) Keeping Good Companies 14, 15.
} 
Report (1992). ${ }^{2}$ The Cadbury Report's frequently cited definition simply states that corporate governance is 'the system by which companies are directed and controlled'. It is worth considering that when Sir Adrian was delivering his committee's landmark review on corporate governance, following the UK pension/superannuation scandal involving Robert Maxwell, 'very few people had actually heard of either email or the internet'. ${ }^{3}$ Cheffins asserts that

'Corporate Governance' first came into vogue in the 1970s in the United States. Within 25 years corporate governance had become the subject of debate worldwide by academics, regulators, executives and investors...

and that by "the end of the 1990s ... "corporate governance" was well entrenched as academic and regulatory shorthand. ${ }^{4}$

Licht provides the following definition of corporate governance:

Corporate governance can be described as the institutional framework that regulates the division and exercise of power in the corporation. 'Power' is the key concept in corporate governance. This definition implies that when individuals are left to their own devices, corporations must rely on an institutional framework in order to function properly, let alone efficiently. ${ }^{5}$

One thing that is clear about the concept of corporate governance is that it has not been conclusively defined. Commentators often speak of corporate governance as an indefinable term, something akin to love, joy or even happiness, which we essentially know the nature of, but for which words do not provide an accurate picture. Nevertheless, in the Australian context, the Australian Securities Exchange Corporate Governance Council Principles (2014) attempt to define it, ${ }^{6}$ as did Justice Neville Owen, the Royal Commissioner in the HIH Insurance Ltd collapse investigation (set up to probe Australia's largest corporate collapse). The term 'corporate governance' is

${ }^{2}$ Committee on the Financial Aspects of Corporate Governance, Report of the Committee on the Financial Aspects of Corporate Governance, Report (1992) ('Cadbury Report').

${ }^{3}$ Michael Adams, 'Global Trends in Corporate Governance’ (2012) 64(9) Keeping Good Companies 516, 517.

${ }^{4}$ Brian R Cheffins, 'The History of Corporate Governance' (Law Working Paper No 180/2012, European Corporate Governance Institute, January 2012) $1<$ http://papers.ssrn.com/sol3/ papers.cfm?abstract_id=1975404>.

${ }^{5}$ Amir N Licht, 'Corporate Governance’ (Entry for the Encyclopaedia of Financial Globalisation, European Corporate Governance Institute, November 2011) $1<$ <ttp://papers.ssrn. com/sol3/papers.cfm?abstract_id=1786382>.

${ }^{6}$ Australian Securities Exchange Corporate Governance Council, 'Corporate Governance Principles and Recommendations $3^{\text {rd }}$ edition' (Report, ASX Corporate Governance Council, March 2014) 3. 
described in the Final Report of the Royal Commission, as 'the framework of rules, relationships, systems and processes within and by which authority is exercised and controlled in corporations. ${ }^{7}$

Harwell Wells, an American historian, states:

The traditional view dates [the modern debates over corporate governance] to 1932 with the publication of Adolf A. Berle and Gardiner Means's The Modern Corporation and Private Property, a work that delineated the separation of ownership and control in the modern corporation and the problems that separation caused. ${ }^{8}$

Wells further notes, in the words of Thompson and Thomas, that: 'For most of the twentieth century, the dominant paradigm of agency in corporate governance within legal academia was that provided by Berle and Means in their classic 1932 book. ${ }^{9}$

Corporate governance took centre stage and became a global phenomenon during the 1990s in conjunction with several developments such as the implementation of market-building structural reforms in former soviet bloc countries, the Asian financial crisis in 1997, and the European Union's continuing efforts toward capital market integration.

During the 1990s the various corporate governance codes came into existence for major stock markets around the world. The first was contained in the abovementioned Cadbury Report in the UK (1992), produced by a committee, chaired by Sir Adrian Cadbury, on the financial aspects of corporate governance. ${ }^{10}$ Based on what was considered good practice, the Code called for:

The wider use of independent non executive directors, with 'independence' defined as 'independent of management and free from any business or other relationship which could materially interfere with the exercise of independent judgment, apart from their fees and shareholding';

\footnotetext{
${ }^{7}$ Commonwealth of Australia, The HIH Royal Commission, The Failure of HIH Insurance (2003) vol 1, xxxiii.

${ }^{8}$ Harwell Wells, 'The Birth of Corporate Governance' (2010) 33(4) Seattle University Law Review 1247, 1247 citing Adolf A Berle and Gardiner C Means, The Modern Corporation and Private Property (Harcourt, Brace \& World, rev ed, 1968).

${ }^{9}$ Robert B Thompson and Randall S Thomas, 'The Public and Private Faces of Derivative Lawsuits’ (2004) 57 Vanderbilt Law Review 1745, 1756 cited in Wells, ibid 1248.

${ }^{10}$ Cadbury Report, above n 2.
} 
The introduction of an audit committee of the board with independent members;

The division of responsibilities between the chairman of the board and the chief executive, or, if the roles were combined, strong independent directors. ${ }^{11}$

The Cadbury review laid down the 'principles based' or 'comply or explain' approach of soft law, rather than the hard law or sledge hammer approach to regulation. It is worth noting that, according to Cheffins, the phrase 'corporate governance' was only 'mentioned once in the Times newspaper up to 1985' and that the Economist refrained 'from using the phrase until 1990. The pattern began to change when the accountancy profession, the London Stock Exchange and the Financial Reporting Council, which regulates accounting standards in the U.K., established in 1991 the Committee on the Financial Aspects of Corporate Governance. ${ }^{12}$

Cheffins continued:

The 1992 Cadbury Report also achieved notoriety internationally. The Cadbury Committee encapsulated its recommendations in a Code of Best Practice and arranged for enforcement by persuading the London Stock Exchange to add the Code as an appendix [to] the London Stock Exchange's listing rules, with listed companies becoming obliged either to comply with the provisions of the Code or explain why they had failed to do so. The Cadbury Code would soon serve as a model for the development of corporate governance codes in various countries around the world. ${ }^{13}$

The follow up UK report, known as the Hampel Report, stated that Cadbury had 'struck a chord in many overseas countries; it has provided a yardstick against which standards of corporate governance in other markets are being measured'. ${ }^{14}$

These observations establish links to the broad set of principles and framework established by the Organisation for Economic Co-operation and Development

\footnotetext{
${ }^{11}$ Bob Tricker, Corporate Governance: Principles, Policies, and Practices (Oxford University Press, $2^{\text {nd }}$ ed, 2012) 12.

${ }^{12}$ Cheffins, above n 4, 18.

${ }^{13}$ Ibid 19.

${ }^{14}$ Committee on Corporate Governance, 'Final Report' (Report, Committee on Corporate Governance, January 1998) 18 ('Hampel Report').
} 
(OECD) and the applied approach of a standards form. ${ }^{15}$ The OECD's definition of corporate governance states that:

Corporate governance involves a set of relationships between a company's management, its board, its shareholders and other stakeholders. Corporate governance also provides the structure through which the objectives of the company are set, and the means of attaining those objectives and monitoring performance are determined. ${ }^{16}$

In Australia, the influence of the 1992 Cadbury Code and the OECD definitions inspired the ASX to establish the Corporate Governance Council with 21 members. The first ASX Corporate Governance Principles were established in 2003, with a new second edition in 2007, and a major amendment on diversity in 2010. A third edition appeared in 2014. The ASX states that corporate governance is

the framework of rules, relationships, systems and processes within and by which authority is exercised and controlled in corporations. It encompasses the mechanisms by which companies, and those in control, are held to account. A good corporate governance code promotes investor confidence. ${ }^{17}$

We may not agree with the precise construction of the corporate governance definition, but, just as with art, we all recognise it when we see it. A deeper question is: what are the benefits of good corporate governance practices?

\section{Benefits of Good Corporate Governance}

Once there is a general agreement on what constitute corporate governance practices, the bigger challenge is to demonstrate that good corporate governance produces actual benefits. ${ }^{18}$ There is overwhelming corroborative

\footnotetext{
${ }^{15}$ See Organisation for Economic Co-operation and Development (OECD), OECD Principles of Corporate Governance (2015) OECD <http://www.oecd.org/corporate/oecdprinciplesof corporategovernance.htm>.

${ }^{16}$ Organisation for Economic Co-operation and Development (OECD), OECD Principles of Corporate Governance (OECD Publications Service, 2004), 11. See also OECD, ibid, as the OECD is currently inviting public comment on the draft 2014 Review of the OECD Principles of Corporate Governance.

${ }^{17}$ Australian Securities Exchange Corporate Governance Council, above n 6, 3.

${ }^{18}$ Michael Head, Scott Mann and Simon Kozlina, Transnational Governance: Emerging Models of Global Legal Regulation (Ashgate Publishing, 2012) and Anona Armstrong, 'Corporate Governance Standards: Intangibles and Their Intangible Value' (2004) 17(1) Australian Journal of Corporate Law 97 cited in Adams, 'Global Trends', above n 3.
} 
and empirical evidence of the impact of sustainability in governance. ${ }^{19}$ Adams, for example, has stated that:

There are numerous studies as to the benefits of corporate governance for global entities, whether they be transnational corporations or the more traditional multinational companies. Around the globe, by far the majority of business entities are privately owned (and/or family businesses) with a small percentage being quoted on a local stock exchange, in a single legal jurisdiction. ${ }^{20}$

Impressive data was produced by Claessens and Yurtoglu ${ }^{21}$ who examined the corporate governance literature from the fields of economics, finance, management and legal scholarship in many countries and jurisdictions over the last decade. The authors' detailed survey of the literature provides evidence of the importance of corporate governance at a number of economic points. These extensive studies provide clear evidence of a link between economic development and corporate governance. The extensive cross-country research demonstrates that corporate governance is central to financial development. Weak corporate governance can be seen to prevail in financial markets that tend to function poorly by global standards. Poor governance increases market volatility and lack of transparency, creating unfair markets. Countries and companies that adopt best practices in corporate governance are not guaranteed success, but provide evidence that good corporate governance improves sustainability and lays the groundwork for long-term success.

The awareness that individual directors and officers are subject to personal (as opposed to corporate) liability has increased the awareness of the need for good corporate governance systems. Personal liability is expressly required by ASX Principle 1 of its Corporate Governance Principles and Recommendations. ${ }^{22}$ Adams states that 'all directors have major concerns with their personal liability'. ${ }^{23}$ Further, the regulators, ASIC and ASX, are clearly improving their enforcement of the corporations law as is evidenced by their improved success

\footnotetext{
${ }^{19}$ See, eg, Alice Klettner, Thomas Clarke and Michael Adams, 'Corporate Governance Reform: An Empirical Study of the Changing Roles and Responsibilities of Australian Boards and Directors' (2010) 24(2) Australian Journal of Corporate Law 148, a report on the implementation of the ASX Corporate Governance Principles between 2003 and 2007.

${ }^{20}$ Adams, 'Global Trends', above n 3, 518.

${ }^{21}$ Stijn Claessens and Burcin Yurtoglu, Corporate Governance and Development - An Update (Global Corporate Governance Forum, 2012) <http://www.ifc.org/wps/wcm/connect/ topics_ext_content/ifc_external_corporate_site/corporate+governance/publications/focus_cas e+studies/focus $+10+$ corporate+governance+and+development+-+an+update $>$.

${ }^{22}$ Australian Securities Exchange Corporate Governance Council, above n 6.

${ }^{23}$ Adams, 'Global Trends', above n 3, 518.
} 
rate in recent years. In 1995 only 12 officers from the 933652 registered companies were gaoled. ASIC had an 81 per cent successful litigation rate in 74 major cases and 7287 misconduct matters. By 2013, there were 2012241 registered companies in Australia and only nine directors were gaoled, but there was a 90 per cent successful litigation rate in 144 major cases and 11682 misconduct matters. ${ }^{24}$

Keay notes:

It is trite to say that companies governed by Anglo-American corporate law are governed by both the general meeting of shareholders and the board of directors, but typically, today, either legislation or the company's articles of association or by-laws will vest the board of directors with very broad general management powers, many of which are then delegated to company managers and officers. Of course, the constitution of the company will determine the breadth of the powers granted and this is likely to differ from jurisdiction to jurisdiction. The general meeting is often granted reserve powers, but these are not frequently exercised. ${ }^{25}$

Keay further observes that " “[a]ccountability for conduct is a pervasive feature of human association” and it operates expressly and implicitly in the field of corporate governance'. ${ }^{26}$

\section{DIVERSITY WITHIN BOARD STRUCTURES AND COMPOSITION}

Board structure (that is, three or more directors on the main board, plus board committees, such as audit, nominations, and risk committees) and board composition (that is, the skill and competency set expected of an effective board) are quite distinct concepts. Most Anglo-American based companies will have a unitary board - that is, a single board of directors which oversees the management of the company. Some European jurisdictions, such as Germany and France, have adopted a bilateral board structure, with distinct advisory and representative boards, with employees elected to specific roles.

\footnotetext{
${ }^{24}$ See Michael Adams, 'Faulty Lines in Corporate Law: Issues for Insurance Policies' (2014) 66(8) Governance Directions 504, 505 Table 1.

${ }^{25}$ Andrew Keay, 'Exploring the Rationale for Board Accountability in Corporate Governance' (2014) 29 Australian Journal of Corporate Law 115, 118.

${ }^{26}$ Ibid 146 quoting A Allen, '2003 Daniel J Meador Lecture: Privacy Isn’t Everything: Accountability as a Personal and Social Good’ (2003) 54 Alabama Law Review 1375, 1377.
} 
Unitary boards and their size (the average membership is 8.4 with the most common distribution being between 8 to 12 members $)^{27}$ have been the subject of extensive commentary. The board's composition, that is who makes up the actual board of directors, will vary depending upon a number of factors. Membership of a board will depend on a candidate showing a list of competencies, including strategic, accounting/finance, and legal expertise together with skills in managing risk and managing people, familiarity with financial markets, and industry knowledge. ${ }^{28}$ The personal qualities that a successful director should have include integrity, business acumen, curiosity, courage, interpersonal skills, genuine interest, and the quality of being an active contributor to board processes. Board effectiveness can be improved by a boardroom culture of mutual respect, honesty and openness that encourages constructive debate, and a diversity of experience, styles, ages, genders and cultural backgrounds. ${ }^{29}$

The Australian Productivity Commission ${ }^{30}$ in its 2009 inquiry into executive remuneration in Australia found that a mix of skills, knowledge and experience on boards is necessary for independent, well-informed decision making which is in the best interest of the company and its shareholders. Diversity on boards can promote independence of views, and enrich debate and constructive analysis. Age-related data from ASIC shows that the average age of the 23448 directors of public companies (whether or not ASX-listed) was 53 years, with 32 per cent over 60, and 27 per cent between $50-60$ years old. ${ }^{31}$ For the larger ASX-listed companies the average age jumped to 59 years. (Similarly, the average age of directors on European listed companies was 58 years.) For top 100 ASX companies the average age for females was 56 and for men 61 years. In respect of ethnic backgrounds the ASIC data shows that 67 per cent of directors were born in Australia, 10 per cent in the United Kingdom, three per cent in New Zealand, 2.8 per cent in the USA, and 2.2 per cent in South Africa. The remaining 15 per cent of the survey sample were from over 100 different countries. Although some studies have proposed a positive relationship between ethnic diversity on boards and performance, ${ }^{32}$ the Corporations and

27 The Korn Ferry Institute, 'The Diversity Scorecard 2013: Measuring Board Composition in Asia Pacific' (Report, The Korn Ferry Institute, 2013) $12<$ http://www.kornferry.com/ institute/721-the-diversity-scorecard-2013-measuring-board-composition-in-asia-pacific > .

${ }^{28}$ Anthea McIntyre, Tomorrow's Boards (Australian Institute of Company Directors, 2011) 15.

${ }^{29}$ Ibid 17.

${ }^{30}$ Productivity Commission, 'Executive Remuneration in Australia', (Inquiry Report No 49, Productivity Commission, 2009) <http://www.pc.gov.au/_data/assets/pdf_file/0008/93590 /executive-remuneration-report.pdf $>$.

${ }^{31}$ This data is also supported by the Korn Ferry Institute, above n 27, 18.

${ }^{32}$ Corporations and Markets Advisory Committee (CAMAC), 'Diversity on Boards of Directors' (Report, CAMAC, March 2009) 25 <https://www.google.com.au/search?q=Corporations 
Markets Advisory Committee report noted that such findings are not conclusive, ${ }^{33}$ as will be discussed below.

None of the steps in Tricker's 2010 report Twenty Practical Steps to Better Corporate Governance related to a need for board diversity. ${ }^{34}$ Tricker did observe that the on-going 'rules versus principles dilemma' reflected a move away from the differences between Anglo-American unitary boards, continental European two tier (supervisory and executive) boards, and Asian approaches such as Japanese keiretsu or Chinese family-orientated company boards. ${ }^{35}$ There is a schism between US corporate governance and the corporate governance of the United Kingdom, Australia, New Zealand, South Africa, India, Singapore and Hong Kong. The former has been enforced by way of regulation and the use of the rule of law (such as the Sarbane-Oxley Act) since the collapse of Enron and WorldCom. By comparison corporations in the latter countries have been asked to comply with voluntary codes, and to explain if necessary why they have not complied. Good corporate governance is about the effectiveness of the governing body rather than merely the compliance code. Corporate governance needs to be distinguished from management, which runs the enterprise. Unlike management, the governing body ensures that the company is well run and is heading in the right direction: that is to say, that there is a balance between corporate strategy and ensuring that it translates into policies and plans for management to action (the performance role). The role of the governing body is to oversee management and accountability (the conformance role). ${ }^{36}$

The ASX's eight central principles of Corporate Governance are intended to clarify the frequently debated role of the board, in the same way that Justice Owen did in the HIH Royal Commission Final Report. It is fair to say that there have been a range of different interpretations of what boards are required to do. The corporate law reform think-tank, the Corporations and Markets Advisory Committee (CAMAC) (unfortunately abolished in 2014 as a government austerity measure), in its 2009 report on diversity on boards of directors, expressly stated: 'The role of the board of directors is to direct a company on

\footnotetext{
+ and + Markets + Advisory + Committee $+($ CAMAC $),+\%$ E2\%80\%98Diversity + on+Boards + of + Directors, + (Report,+CAMAC,+March+2009\&ie=utf-8\&oe=utf-8\&gws_rd=cr\& ei=NgGvVYi9LYLYmgXm5YGgBg>.

${ }^{33}$ Ibid 51.

${ }^{34}$ R I Tricker, 'Twenty Practical Steps to Better Corporate Governance' (Corporate Secretaries International Association, March 2010) Corporate Secretaries International Association, March, 2010.

35 Ibid 3.

${ }^{36}$ Ibid 8.
} 
behalf of the shareholders.' ${ }^{37}$ This statement represents a shareholder-centric view of what corporate governance is. The traditional formulation is that the role of the board is to direct the company on behalf of the shareholders, setting the strategic direction and aims of the company, providing resources for their implementation, and directing or overseeing the management of the company's business, and compliance with its obligations. The 2009 report never uses the term 'monitoring', in fact. The closest it gets to the concept of monitoring is the expression 'overseeing'. 38

\section{MAKE-UP OF A BOARD OF DiRECTORS - QUESTIONS OF DIVERSITY}

The heart of the question is: who sits on the board of directors and what is the actual composition of the board of directors? The make-up of the board is absolutely critical to the success of the company. There are a variety of definitions of what is meant by diversity of board membership. Diversity, both in its gender-specific and broader meaning, impacts board composition.

The relationship between good governance and board diversity has been the subject of international research. A study by Mahadeo, Soobaroyen and Hanuman, ${ }^{39}$ on the emerging economy of Mauritius, found very positive links between the key elements of board diversity (or heterogeneity) amongst listed companies operating in an emerging economy (Mauritius), and the extent to which these influence financial performance. With respect to age it was found that ' $[\mathrm{t}]$ he inherent nature of company management and career progression does play a significant role in having a board which mainly consists of mature, experienced and by default older directors'. ${ }^{40}$ Mahadeo, Soobaroyen and Hanuman observe that:

Whilst an age-diverse board may enable some division of labour and encourage board development and learning, it relies on the assumption that directors will play their selected roles and does not address the likely shortterm issues of communication and trust arising from generational gaps. On the other hand, a homogeneous board is likely to avoid these latter issues but

${ }^{37}$ CAMAC, above $\mathrm{n} 32,11$.

${ }^{38}$ Ibid.

39 Jyoti Mahadeo, Teerooven Soobaroyen and Vanisha Hanuman, 'Board Composition and Financial Performance: Uncovering the Effects of Diversity in an Emerging Economy’ (2012) Journal of Business Ethics 375.

40 Helen Kang, Mandy Cheng and Sidney J Gray, 'Corporate Governance and Board Composition: Diversity and Independence of Australian Boards' (2007) 15(2) Corporate Governance 194, 197 cited by Mahadeo, Soobaroyen and Hanuman, ibid 377. 
composition may encourage complacency, cronyism, lack of interest in new ideas/strategies and decisions based on compromises. ${ }^{41}$

Interestingly, Mahadeo, Soobaroyen and Hanuman note that companies were more reluctant to share age related information than other information. Only 26 companies made that data available to the authors. ${ }^{42}$

The commentary on Recommendation 1.5 of the ASX Corporate Governance Principles and Recommendations states that,

while the focus of this Recommendation is on gender diversity, diversity has a much broader dimension and includes matters of age, disability, ethnicity, marital or family status, religious or cultural background, sexual orientation and gender identity. ${ }^{43}$

The 2009 CAMAC Report on diversity focused on gender, age and ethnicity as the major components of diversity. More explicitly in its conclusion, it stated:

In relation to board diversity in Australian public listed companies, gender is just one, if one of the most obvious, of the measures of board diversity. Similar issues may arise with age, ethnicity or other measureable or less tangible aspects of differentiation. ${ }^{44}$

Alicia Yi comments on the effect of diversity. She states:

Diversity will be an important factor in determining future winners in Asia Pacific, one of the world's most exciting and dynamic markets. The real question is whether boards and senior leadership are fully prepared to guide companies in this environment and to take Asia Pacific enterprises to the next level. ${ }^{45}$

Du Plessis, O’Sullivan and Rentschler suggest that

'diversity' at board level encompasses a number of human attributes, of which gender is but one. The United States Department of Agriculture Strategic Planning Task Force on Diversity provides the following definition: '[D]iversity is differences among people with respect to age, class, ethnicity, gender, physical and mental ability, race, sexual orientation, spiritual

\footnotetext{
${ }^{41}$ Mahadeo, Soobaroyen and Hanuman, above n 39, 378 (references omitted).

42 Ibid 381.

${ }^{43}$ Australian Securities Exchange Corporate Governance Council, above n 6, 12.

${ }^{44}$ CAMAC, above $\mathrm{n} 32,51$.

${ }^{45}$ The Korn Ferry Institute, above n 27, 4.
} 
practice, and other human attributes.' Nonetheless, the board diversity debate is dominated by gender — both in Australia and abroad. ${ }^{46}$

A more sustainable proposition, drawing on the report from CAMAC, ${ }^{47}$ is that enlightened companies can be expected to perform better than others and that they will inevitably be the ones who seek talent from all sources, with gender being a very secondary consideration for them. In other words, diversity in itself is not relevant to the issue of effective governance. Rather, what counts is a studied approach to the constitution of a governing board, with a mind open to available talent. While a mix of backgrounds and perspectives may be beneficial on a board, diversity should not be pursued at all costs. Instead, boards are best constituted around a common purpose, and on the basis of the ability of the board members to work together. CAMAC recommendations state that

the ultimate question in terms of the governance culture of Australian companies is whether the environment and current practices are conducive to boards being constituted with well-qualified candidates in an effective mix for the furtherance of their corporate purposes. ... [M]ore transparent board processes, and more information about the reasons for putting forward new directors, will assist shareholders in questioning a board's approach or in voting on board appointments. ... [T] business leaders and others to encourage companies to take a more open approach to board selection, and to facilitate opportunities for women to gain experience that will equip them for board roles. ${ }^{48}$

The ASX Listing Rules and the 2010 amendments to the ASX Corporate Governance Principles and Recommendations ${ }^{49}$ require companies to adopt policies of greater diversity on boards and to disclose progress made. While there is unlikely to be a quick fix, encouragement of a more robust and open approach to board appointments and attention to any impediments in the area of executive management should contribute to change, including more diversity through better utilisation of valuable talent.

One report, produced by the Korn Ferry Institute, quotes the Chair of Telstra Ltd, Catherine Livingstone, as saying: 'While diversity of gender is desirable

\footnotetext{
46 Jean du Plessis, James O’Sullivan and Ruth Rentschler, 'Multiple Layers of Gender Diversity on Corporate Boards: To Force or Not to Force?' (2014) 19(1) Deakin Law Review 1, 3.

${ }^{47}$ CAMAC, above $\mathrm{n} 32,2$.

${ }^{48}$ Ibid 52-3.

${ }^{49}$ Corporate Governance Principles and Recommendations, above n 6.
} 
on boards, diversity of skills, experience and ideas are of equal importance' ${ }^{50}$ In the same report, the Managing Director of the ASX Ltd, Elmer Funke Kupper, is quoted as stating:

Research shows that companies with diverse management teams and boards perform better. It seems obvious - and yet progress toward improving diversity can be frustratingly slow ... Real change, however, comes from a belief that businesses need to tap into $100 \%$ of the available talent, not $50 \%{ }^{51}$

The Korn Ferry Institute's report surveyed 57 female directors in Australia who were appointed to listed boards after 2010, when the Australian Securities Exchange introduced changes to its Corporate Governance Principles and Recommendations on the reporting of diversity. The survey examines the paths women took to arrive on the boards of Australia's largest listed companies and highlights the importance of a strong network, usually gained throughout the course of an executive career, for women who seek board roles.

This has been followed by a 2014 report by KPMG on behalf of the ASX, providing an analysis of the disclosures on diversity made by a selection of ASX listed entities with financial years that ended between 31 December 2012 and 30 December 2013. It focuses on an analysis of the second full year of reporting and provides for comparisons to be made and trends drawn between the first and second full years of reporting. The report's primary finding is that there is a need to 'recognise the benefits of diversity'. ${ }^{2}$ The report observes that many organisations expressed the view that a broader workforce of people with diverse skills and backgrounds was beneficial to the organisation. These organisations also reported improvements to the bottom line and better results for shareholders and other stakeholders. Some of the key benefits disclosed by companies with diverse boards include enhanced corporate performance, reputation, and shareholder value. Research has shown that increased gender diversity on boards is associated with better financial performance. ${ }^{53}$

\footnotetext{
${ }^{50}$ The Korn Ferry Institute, 'Beyond 'if not, why not': The Pathway to Directorship for Women in Leadership' (Report, The Korn Ferry Institute, 2014), 3 <http://www.kornferry.com/ institute/787-beyond-if-not-why-not-the-pathway-to-directorship-for-women-in-leadership>.

${ }^{51}$ Ibid 2.

${ }^{52}$ KPMG, 'ASX Corporate Governance Council Principles and Recommendations on Diversity: Analysis of Disclosures for Financial Years Ended between 31 December 2012 and 30 December 2013' (Report, KPMG, 2014) 16.

53 Reibey Institute, 'ASX 500 - Women Leaders' (Research Note, 30 June 2011) $<$ http://www.reibeyinstitute.org.au/wp-content/uploads/2011/10/ASX500_Women-Leaders2011.pdf $>$ and Catalyst, The Bottom Line: Corporate Performance and Women's Representation on Boards (October 2011), Catalyst <http://www.catalyst. org/system/files/The_Bottom_Line_Corporate_Performance_and_Womens_Representation_o
} 
Further, the report includes a discussion going 'beyond gender' which states that:

While gender diversity is the focus of the Diversity Recommendations, the majority of entities within all three samples established policies with a broad interpretation of diversity that covered more than gender. ... Examples included the establishment of policies on indigenous education and employment, and programs to support mature age employees to plan their career and retirement..$^{54}$

The academic literature and research on women on boards, can be useful in the examination of the diversity issue on boards of directors. Nagarajan applies complex regulatory theory in her examination of the key reasons for the lack of women on boards. ${ }^{55}$ Her study notes that:

Tackling the gender gap on the boards of public listed companies provides us with an accessible and fascinating site to reconsider the effectiveness of the variety of regulatory tools and to reflect on the role of the various participants in the regulatory game in Australia. Whereas a small number of governments have elected to rely on hard laws to action this systemic shift, many other nations, including Australia, have outsourced this task to non-state regulators who have relied on soft laws to do the job. ${ }^{56}$

The four main reasons for increasing the representation of women on boards are, as stated by Nagarajan: (1) making boards more democratic representations of societies' diversity; (2) improving decision making by increasing the range of views, values and experiences represented; (3) improving corporate profitability; and (4) enhancing the corporate image for shareholders, employees and consumers. ${ }^{57}$

It is true to say that all these arguments are both interrelated and highly contested. Reviewing the existing regulatory toolkit available to change behaviour is, in fact, directly taken from the playbook of Ayres and Braithwaite. ${ }^{58}$ More accurately, Nagarajan observes that the approach of

\footnotetext{
n_Boards.pdf $>$ cited at footnote 11 of ASX Corporate Governance Principles and Recommendations KPMG, above n 52, 77.

${ }^{54} \mathrm{KPMG}$, above n 52, 18.

${ }^{55}$ Vijaya Nagarajan, 'Regulating for Women on Corporate Boards: Polycentric Governance in Australia’ (2011) 39 Federal Law Review 255.

56 Ibid 255.

${ }^{57}$ Ibid 257.

${ }^{58}$ See Ian Ayres and John Braithwaite, Responsive Regulation: Transcending the Deregulation Debate (Oxford University Press, 1992) and John Braithwaite and Peter Drahos, Global Business Regulation (Cambridge University Press, 2000).
} 
'[p]olycentric governance is not a panacea. But it has resulted in experimental efforts with multiple benefits at multiple levels'. ${ }^{59}$ In conclusion, polycentric governance does not provide a straightforward way to encourage compliance with diversity norms or to facilitate stakeholder enforcement of gender or other diversity on boards of directors.

A further study by Adams and Ferreira states that 'despite the importance of gender diversity in the policy debate, relatively little research links diversity and corporate governance'. ${ }^{60}$ Building on the detailed work of Carter, Simkins and Simpson did not find a definite positive relationship between gender and ethnic diversity on the board and corporate performance. ${ }^{61}$ However, Adams and Ferreira do find a positive link between board diversity and effectiveness, albeit one that is more complex than previous studies have found. ${ }^{62}$ Kang, Cheng and Gray state that '[a]mong the most significant governance issues currently faced by the modern corporation are those relating to diversity, such as gender and age, and independence of directors' ${ }^{63}$ Although there has been mixed evidence and constant debate regarding the effect of board composition on performance, diversity of board membership is still considered desirable. ${ }^{64}$ Wang and Clift similarly observe that,

in spite of some progress during the past 20 years, corporate boards in the UK, USA and Australia remain dominated by white males. ... [T] homogeneity of corporate boards may raise significant ethical, political and economic issues, while women and minorities are continuing to become a larger proportion of the workforce. ${ }^{65}$

The empirical evidence provided in these studies and the detailed assessment of the top 500 companies listed on the ASX demonstrates a link between board structure and financial performance. The study supports an equity argument for increased diversity.

\footnotetext{
${ }^{59}$ Nagarajan, above n 55, 275.

${ }^{60}$ Renée B Adams and Daniel Ferreira, 'Women in the Boardroom and their Impact on Governance and Performance' (2009) 94 Journal of Financial Economics 291, 292.

61 David A Carter, Betty J Simkins and W Gary Simpson, 'Corporate Governance, Board Diversity and Firm Value' (2003) 38 Financial Review 33.

${ }^{62}$ Adams and Ferreira, above n 60, 307.

${ }^{63}$ Kang, Cheng and Gray, above n 40, 194.

${ }^{64}$ Ibid.

${ }^{65}$ Yi Wang and Bob Clift 'Is There a "Business Case” for Board Diversity?' (2009) 21(2) Pacific Accounting Review 88, 88.
} 


\section{INTERNATIONAL EXPERIENCE}

The international experience with diversity of board membership is not as clear as one might expect. Clearly many countries have a continuing focus on the gender of board members and some countries are encouraging diversity. The evidence is mixed as to the success of any one country in producing greater diversity on boards or even increasing the level of female directorship. The exceptions are countries where there are mandatory quotas with consequences for companies which fail to fulfil these quotas. Norway, with its 40 per cent requirement is leading the way. Other European and some Asian countries are following a similarly drastic approach in order to accelerate through legislative mandate what should be occurring either naturally or voluntarily.

The 2013 Korn Ferry Institute diversity report provides some valuable independent data across nine Asian countries on board membership. ${ }^{66}$ This was the second comprehensive study of corporate boards at the 100 largest listed companies in key markets across the Asia Pacific region, including Australia, China, Hong Kong, India, Japan, Malaysia, New Zealand, Singapore and South Korea. This report builds on findings from 2011 and provides new insights into the progress of board composition diversity in the Asia Pacific region. Its findings indicate

that in a few countries, most notably Australia, companies are beginning to fundamentally reshape their boards to embody a diverse set of professional experience, personal background, expertise and gender. Conversely, companies in countries such as Japan and Korea have made little progress in this area, underscoring issues that could limit their prospects when squeezed between more progressive companies in the U.S and massive players from China. ${ }^{67}$

The report is particularly useful as it goes beyond gender diversity and examines age and ethnic diversity, as well as diversity based on 'age and education'.

The Korn Ferry Report states that:

By ensuring sufficient diversity, high-performing boards can be assured that board decisions will be vigorously debated by individuals with different perspectives leading to improved board monitoring, better board meeting attendance rates, and causes boards [sic] to be more stakeholder focused boosting shareholder value and representing customers, employees, and

\footnotetext{
${ }^{66}$ The Korn Ferry Institute, above n 27, 9.

${ }^{67}$ Ibid 4.
} 
business partners... A diverse group of directors is more likely to raise questions, challenge the status quo, or spot new opportunities. Appointing directors from different ethnic, age and educational backgrounds can immediately add multiple perspectives to the oversight lens. ${ }^{68}$

The general thrust of the Report is very similar to that of the 2009 CAMAC Report, ${ }^{69}$ stressing the need for increased transparency in relation to appointments and disclosures. As stated in the Korn Ferry report:

The key to increasing diversity, and also addressing other demands for directors to be independent, competent, and committed, is to have a robust and transparent board nomination process. Prevailing practices of recruiting directors through personal networks or selecting corporate leaders who already sit on other boards need to be phased out in favor of a more formal, professionally managed selection process designed to gather the widest variety of candidates. Gaps and weaknesses in the current board need to be identified and a framework of competencies and attributes desired in new directors developed. ${ }^{70}$

The Korn Ferry Institute report research demonstrates that the issue of age diversity in relation to boards arises across eight Asian markets. It notes that 'China and Hong Kong have the highest percentage of companies with directors from two or more generations. Japan has the highest percentage of companies with single generation boards, followed by South Korea'. ${ }^{71}$

Of even greater consequence is the issue of ethnic diversity, as this employs assumptions as to race and culture, which are not precise concepts. The Korn Ferry Institute study found that:

More than half of the companies in Australia, China, India, Japan, New Zealand and South Korea have boards consisting solely of board members from a single ethnicity. The majority of boards, other than those in Australia and China, are composed of three or more ethnic groups, with Malaysia and Singapore having the most. ${ }^{72}$

The work of Du Plessis, Saenger and Foster further examines the international board diversity issue, in relation to Europe (Norway, France, and Germany), Australia and South Africa. Because the debate on board diversity is wider than just a debate on gender diversity their study also reviews cultural, national, race

\footnotetext{
${ }^{68}$ Ibid 33.

${ }^{69}$ CAMAC, above n 32, 2.

${ }^{70}$ The Korn Ferry Institute, above n 27, 33.

${ }^{71}$ Ibid 17.

72 Ibid 18.
} 
and age diversity, as well as diversity among stakeholders. The authors assert that:

At both a national and EU level, there have been serious attempts to address board diversity, in particular, the issue of underrepresentation of women on the boards of public companies. The European countries Belgium, Norway, France, the Netherlands and Spain have taken the lead in introducing legislation to mandate up to $40 \%$ women on the boards of public companies. ${ }^{73}$

There are, however, several other countries where it is argued that the same could be achieved, over time, through voluntary codes of conduct. It is therefore clear that there is currently a deep divide as to what method should be used to achieve board diversity generally, and gender diversity in particular. $^{74}$

The authors further observe that,

since 2010, there have been serious efforts to make sure that more women are appointed to Australian boards, especially for listed companies. The gender imbalance on boards is currently being addressed by the Australian Securities Exchange's (ASX) Corporate Governance Principles and Recommendations, which is the voluntary code of corporate governance applying to all listed companies through the ASX's Listing Rules. It is not difficult to predict that if the right gender balance is not going to be achieved through the voluntary code of corporate governance, as in some other countries ... mandatory quotas of women on Australian boards will be dictated by legislation. ${ }^{75}$

Moreover, Du Plessis, Saenger and Foster note that: '[T]he debate on board diversity in Australia is dominated by gender diversity. However, it is clear that gender diversity is seen in the broader context of board diversity generally, including age, [ethnic] and cultural diversity. ${ }^{96}$

New Zealand (NZ) is trying to directly increase the number of females on boards, but by 2012 the incidence of women directly participating in governance roles was - of all directors in the top $100 \mathrm{NZ}$ companies by capitalisation on the New Zealand Stock Exchange (NZX) - only 14.75 per cent. This is despite the fact that it is recorded that 55 per cent of the top 100

\footnotetext{
${ }^{73}$ Jean J du Plessis, Ingo Saenger and Richard Foster, 'Board Diversity or Gender Diversity? Perspectives from Europe, Australia and South Africa’ (2012) 17(2) Deakin Law Review 207, 222.

${ }^{74}$ Ibid.

${ }^{75}$ Ibid 223.

${ }^{76}$ Ibid 230.
} 
NZX companies have at least one female director. The NZ census report states that:

The United Nations Committee on the Elimination of Discrimination Against Women told New Zealand in 2012 that 'while there is co-operation between the Government and the private sector to identify targets for the advancement of women in decision-making positions, the targets, goals and time frames set out are not sufficient and may be a symptom of regression rather than progress in women's representation'. ${ }^{77}$

Du Plessis, O’Sullivan and Rentschler have examined whether diversity of corporate board membership is desirable, and how that diversity can best be achieved, including whether diversity is better achieved by mandatory requirements or voluntary targets. ${ }^{78}$ Whilst recognising that diversity is broader than gender diversity, the authors focus on gender debates, providing a framework for analysis of a topical issue. The authors take the view that board gender diversity represents both governance and community expectations but that change is progressing slowly in Australia. They present arguments both for and against board gender diversity, and examine the current state of board composition, while also disclosing their position that board gender diversity aids decision-making by bringing greater heterogeneity to boards.

Du Plessis, O’Sullivan and Rentschler note as follows:

A change in cultural attitudes, so that the advantages of diversity are recognised and female participation encouraged, will increase the quantity of qualified, experienced female directors in a sustainable and productive manner. Current data demonstrates improvement in Australia's board-level gender diversity, with 22 per cent of all new 2012 ASX 200 board appointments being women (or a total of 41 women). Strong progression towards equitable representation has continued over three years, with 68 female appointments in 2011 (comprising 28 per cent of the total) and 56 (comprising 25 per cent of new appointments) in $2010 .^{79}$

The Australian position has been impacted by the third edition of the ASX Corporate Governance Council's Corporate Governance Principles and Recommendations, as amended and adopted in 2010. The ASX Corporate Governance Council, following public consultation, made amendments to the second (2007) edition and refined the relevant Principle 1. In the third edition,

\footnotetext{
${ }^{77}$ New Zealand Human Rights Commission, ‘New Zealand Census of Women's Participation 2012' (Census, 2012) 3.

${ }^{78}$ Du Plessis, O’Sullivan and Rentschler, above n 46.

${ }^{79}$ Ibid 27.
} 
Recommendations 1.4 and 1.5 were added to include accountability and diversity. Principle 2 in the document deals with the issue of structuring the board to add value. Specifically, Recommendation 2.1, which provides that '[t]he board should establish a nomination committee', requires boards to report upon director recruitment, including procedures to consider talent from diverse sources.

The 2009 CAMAC Report had recommended that

a starting point in any move to encourage greater gender (or other) diversity on boards is to ... make their appointment processes more transparent and to formalise their processes for keeping board composition under review in the light of performance and changing needs. ${ }^{80}$

No change to the principle was made; however, additions were recommended under 'selection and appointment process and re-election of directors', with the aim of promoting diversity by encouraging companies to consider broad sources when recruiting directors. Principle 3 aims to promote ethical and responsible decision-making, with Recommendation 3.1 representing the most significant amendment to the ASX's Corporate Governance Principles and Recommendations. It requires the establishment of a code of conduct for its directors, senior executives and employees and the disclosure of that code or a summary of it.

The ASX's Corporate Governance Principles and Recommendations are developed on an 'if not, why not' basis, enabling listed companies to elect not to adopt any recommendation, provided that they disclose reasons why the recommendation was not adopted. Since their introduction during 2003, the principles and recommendations have been voluntary. However, the cooperative premise of the document and its value as a tool to analyse the corporate governance performance of Australian companies has ensured that it has been adopted by almost all listed companies. The Australian framework supports the principle that it is ultimately 'for the market to pass judgement on the corporate governance practices of Australian companies' and it is hoped that the 'cooperative goodwill of listed entities' will continue with regard to board gender diversity, avoiding the need for legislative intervention. ${ }^{81}$

${ }^{80}$ CAMAC, above $n$ 32, 52-3.

${ }^{81}$ Klettner, Clarke and Adams found that most listed companies had fully adopted the ASX Corporate Governance Principles: Klettner, Clarke and Adams, above n 19, 151. 


\section{Selecting BoARd Members - Direction of TARGETS OR QUOTAS}

The heart of the debate around board structure is how to encourage or mandate a diverse board membership. A variety of regulatory techniques have been applied in the last 50 years in order to achieve this. Those techniques have progressively moved up the Braithwaite ${ }^{82}$ pyramid of regulatory enforcement from cooperation to punishment for lack of disclosure (enforced by civil or even by criminal sanctions) to the imposition of formal quotas. The most common techniques set targets and use disclosure as a way of using societal and public pressure to cause change.

There has been some academic work on the use of either targets or quotas to produce societal change specifically linked to the gender diversity of boards. In 2014 Kogut, Colomer and Belinky stated that: 'In many countries, quotas have often been employed as a means to assure greater equality in outcome as well as in access and opportunity. ${ }^{83}$ In the past decade there has been a push for political elections to mandate specific gender quotas and now this push is moving towards the private sector. Quotas are useful in this regard to transform the system from one of high inequality into a system with the critical mass of female directors needed to produce structured equality. The small amount of research on the selection of directors has consistently found tokenism and dominant male homophily (the preference for associating with like people). ${ }^{84}$ Female representation on boards has, globally, stagnated at the 15 per cent level on average, and tokenism is a basic response to external pressures. Director selection based on homophily is an important element in board composition. ${ }^{85}$

Academics have noted that '[i]n the context of improving structural equality at the top of the corporation for women and minorities, the implication is that a

\footnotetext{
${ }^{82}$ Ayres and Braithwaite, above n 58; Braithwaite and Drahos, above n 58; and Marina Nehme, Margaret Hyland and Michael Adams, 'Enforcement of Continuous Disclosure: The Use of Infringement Notice and Alternative Sanctions' (2007) 21(2) Australian Journal of Corporate Law 1.

${ }^{83}$ Bruce Kogut, Jordi Colomer and Mariano Belinky, 'Structural Equality at the Top of the Corporation: Mandated Quotas for Women Directors’ (2014) 35 Strategic Management Journal 891.

${ }^{84}$ Anna Stafsudd, 'People are strange when you're a stranger: senior executives select similar successors’ (2006) 3(3) European Management Review 177.

85 James Westphal and Laurie Milton, 'How Experience and Network Ties Affect the Influence of Demographic Minorities on Corporate Boards' (2000) 45(2) Administrative Science Quarterly 366.
} 
small quota can achieve large structural consequences, and such a policy is deserving of consideration'. ${ }^{86}$ They also explain as follows:

Recent studies suggest that the lack of gender diversity in the boardroom is troublesome, raising ethical and performance implications as well as general stakeholder management issues. In 2012, only 16\% of American board seats were filled by women. Meanwhile, women represent almost $60 \%$ of the workforce in the United States. ... Board gender diversity, simply defined as the proportion of women on the board, is also gaining in publicity as shareholders file numerous proposals and institutional investors release policy statements to contest the status quo. Meanwhile countries such as Norway and Israel spawn a rich conversation recorded in the American public press and stimulate U.S. regulating bodies ... to further examine the issue. ${ }^{87}$

The UK position on voluntary targets is articulated by Lord Davies's announcement in 2011 that London Stock Exchange listed companies should have 25 per cent female directors by $2015 .^{88}$ As of March 2014, the third annual progress report into Women on Boards shows that 20.7 per cent of board positions in FTSE $100^{89}$ companies are female, compared with the 2011 result of only 12.5 per cent. Real progress appears to have been made by the UK's largest companies, but this is not as yet the case across all public companies. Ninety-eight out of the FTSE100 companies have at least one female director. With 50 additional female director appointments to the boards of FTSE100 companies the 25 per cent target would be achieved. As of March 2014, 25.5 per cent of non-executive directors and 6.9 per cent of executive directors were female. Of the 1117 FTSE100 board positions 231 were female, and women accounted for 28 per cent of all board appointments in the 2013/14 timeframe. In respect of the FTSE250, females represented 15.6 per cent of overall board directorships, and 33 per cent of board appointments. However, 48 of the top 250 companies still had all male boards. ${ }^{90}$

The Institute of Chartered Secretaries and Administrators in the UK conducts a twice-yearly survey of company secretaries in FTSE350 companies: the FT-

\footnotetext{
${ }^{86}$ Kogut, Colomer and Belinky, above n 83, 901.

${ }^{87}$ Elise Perrault, 'Why Does Board Gender Diversity Matter and How Do We Get There? The Role of Shareholder Activism in Deinstitutionalizing Old Boys' Networks' (2014) 4 Journal of Business Ethics (online) 149.

${ }^{88}$ Lord Davies of Abersoch, 'Women on Boards' (Report, Lord Davies of Abersoch, March 2014) 4.

89 Financial Times Stock Exchange (FTSE), FTSE 100, 28 November 2014 $<$ http://www.ftse.com/analytics/factsheets/Home/DownloadConstituentsWeights/?indexdetail $\mathrm{s}=\mathrm{UKX}>$.

${ }^{90}$ Lord Davies of Abersoch, above n 88.
} 
ICSA 'Boardroom Bellwether Survey'. It shows that between the first survey conducted in March 2012 to the latest conducted in July 2014 company secretaries expected board diversity to increase with respect to business experience (from 70 per cent to 87 per cent of respondents), and geographical area (from 30 per cent to 61 per cent of respondents). However, only 53 per cent of respondents expected Lord Davies's 25 per cent target of female directors to be met by 2015. When surveyed about their own companies, 16 per cent reported that their boards were not diverse, and 18 per cent did not think their company could meet the 25 per cent target. The use of quotas to meet targets was very unpopular: only 5 per cent of respondents thought that the UK is likely to introduce quota legislation, and 77 per cent regarded it as unlikely. When asked whether a sufficient pipeline of high quality female candidates existed to fill future board positions, only 16 per cent of respondents thought the supply sufficient to support a sustainable pool of talented board-ready women in the future, and 48 per cent believed it would be insufficient. In 2012 up to 60 per cent thought that the pipeline was insufficient, and 11 per cent thought it was sufficient. ${ }^{91}$

In Australia, the former Federal Sex Discrimination Commissioner, Elizabeth Broderick has said 'getting more women onto boards ... is not just about gender equity. It's also about our desire to remain internationally competitive. No country, industry or organisation can afford to waste the skills of more than half its population'. ${ }^{92}$ BlackRock, one of the world's leading investment management and advisory companies, describes Australia's rate of change in female board representation as 'glacial', ${ }^{93}$ with 18.2 per cent of directors of ASX-200 companies being female, and 41 companies having all female boards. For ASX201-300 companies the percentage falls to just 7.6 per cent in the Board Diversity Index 2013. ${ }^{94}$ Four years after the ASX Guidelines adopted a diversity disclosure provision, KPMG reports that:

Overall, although the results show an improvement in the level of reporting and disclosures from last year, it is evident that many organisations still have a long way to go in terms of establishing clear and measurable objectives and

\footnotetext{
${ }^{91}$ Peter Swabey, In Tune but out of Touch (1 September 2014) Governance \& Compliance (online) $50<$ https://www.icsa.org.uk/products-and-services/governance-and-compliance/ features/sept-2014-in-tune-but-out-of-touch>.

92 Elizabeth Broderick, 'Mandatory Quotas May Be Needed on Boards', Australian Financial Review (Sydney), 8 April 2014, 63.

${ }^{93}$ BlackRock, 'Glacial Change in Diversity at ASX 200 Companies: Can Corporate Australia Escape the Imposition of Diversity Quotas?' (Report, BlackRock, 2012) $<$ https://www.wgea.gov.au/sites/default/files/BlackRock_Glacial_Change_in_Diversity_at_A SX200_companies.pdf $>$.

${ }^{94}$ Women on Boards, ASX 2012 < http://www.womenonboards.org.au/pubs/bdi/2012/asx.htm>.
} 
working towards improving the number of women at all levels across the organisation. ${ }^{95}$

Du Plessis, Saenger and Foster put a strong argument for the need for quotas. The authors give 'positive examples of countries with statutory quotas', and express the rationale for legislative quotas: 'The first argument in favour of quota legislation is obvious, that gender quota laws have achieved the desired results by increasing the percentage of women on boards. This fact is stressed by national political stakeholders as well as EU institutions. ${ }^{96}$ Further, they argue that:

The research undertaken shows that in Europe, Australia and Germany, the debate on board diversity is seen as wider than just a debate on gender diversity. Cultural, race, age, stakeholder and nationality diversity also form part of the debate. In several European countries, as well as in Australia and in South Africa, efforts are being made through voluntary codes of conduct to strive for board diversity. Gender diversity is a particular focus in all jurisdictions. ${ }^{97}$

It can be predicted that in future more women will be appointed to senior executive positions and to boards in Europe, Australia and South Africa. What the effect of that will be from a business point of view is impossible to predict. There is no doubt, however, that women will have a greater say in the corporate world in the next five years than they have ever had before.

Many nations are now developing either mandatory diversity requirements or detailed targets to be met over the next five years. This will see rapid change in governance, disclosures and information. Examples from the Asia Pacific region ${ }^{98}$ include Malaysia's June 2011 announcement that its cabinet had approved a policy that women must comprise at least 30 per cent of decisionmaking positions in the corporate sector, giving companies 5 years to comply. Also, the Monetary Authority of Singapore, in May 2012, approved a revised Code of Corporate Governance for companies listed on the Singapore Stock Exchange. The Code operates on a 'comply or explain' basis and, for the first time, makes reference to gender diversity. Guideline 2.6 of the Code of Corporate Governance recommends that ' $[\mathrm{t}] \mathrm{he}$ Board and its board committees

\footnotetext{
${ }^{95}$ KPMG, above n 52, 4.

${ }^{96}$ Du Plessis, Saenger and Foster, above n 73, 245-6.

${ }^{97}$ Ibid 248.

${ }^{98}$ The Korn Ferry Institute, above n 27, 6.
} 
should comprise directors who as a group provide an appropriate balance and diversity of skills, experience, gender and knowledge of the company'. ${ }^{99}$

In September 2012, the Stock Exchange of Hong Kong issued a public consultation paper specifically on board diversity and proposed a code provision recommending that the nomination committee or the board should have a policy concerning board diversity. As of December 2012, the Lok Sabha (Lower House) of the Indian Parliament passed the Companies Act 2011 which states that prescribed classes of companies should have at least one female director.

Globally, governments and stock exchanges are continuing to enhance corporate governance rules and guidelines to promote better diversity on boards. A number of countries, especially in Europe, have addressed the issue of gender imbalance on boards by changing corporate governance codes or implementing quotas. However, more can be done, such as requiring boards to set diversity targets and to disclose these targets, as well as plans for achieving them. Without greater intervention by regulators, women will continue to be significantly underrepresented on boards in the foreseeable future, and other aspects of diversity are unlikely to improve. ${ }^{100}$

The composition of a board should reflect the company's target market and customer base. Companies that rely solely on men to make strategic decisions on products, innovation, and growth are short-changing themselves; they are forgoing the fiscal and cultural benefits that women in leadership bring. Spender, ${ }^{101}$ commenting on issues of gender diversity raised in Branson's earlier article and research, ${ }^{102}$ examines whether the progress of women's appointment onto boards in Australia continues to be 'glacial'. ${ }^{103}$ She concludes

99 Monetary Authority of Singapore, Code of Corporate Governance (May 2012) 6 $<$ http://www.mas.gov.sg/regulations-and-financial-stability/regulatory-and-supervisory-frame work/corporate-governance/corporate-governance-of-listed-companies/code-of-corporategovernance.aspx>.

100 The Korn Ferry Institute, above n 27, 7.

101 Peta Spender, 'Gender Diversity on Boards in Australia - Waiting for the Great Leap Forward?’ (2012) 27(1) Australian Journal of Corporate Law 22.

102 Douglas M Branson, No Seat at the Table: How Corporate Governance and Law Keep Women out of the Boardroom (New York University Press, 2007) and Douglas M Branson, The Last Male Bastion: Gender and the CEO Suit at America's Public Companies (Routledge Press, 2010).

103 Anne Ross-Smith and Jane Bridge, “'Glacial at Best”: Women’s Progress on Corporate Boards in Australia' in Susan Vinnicombe et al (eds), Women on Corporate Boards of Directors: International Research and Practice (2009), 63. 
that it does, and considers the cultural and structural determinants contributing to the undoubtedly slow progress.

Spender concludes that the representation of women on boards should broadly reflect their workforce participation. This claim may be justified by their contribution as economic citizens, but goes further. In particular, the role that women play on the boards of ASX 200 companies is a measure of women's democratic leadership, and low rates of representation undervalue civic participation by women. Conversely, justifications for higher rates of participation based on corporate performance are not only methodologically doubtful but also unnecessary and potentially condescending to women. ${ }^{104}$

Spender concludes as follows:

[T]he number of women on Australian boards is still disappointingly low, but collaborative approaches between corporations, government and civil society has [sic] not only generated significant debate about the topic but considerable societal pressure for change. ${ }^{105}$

Klettner, Clarke and Boersma make further observations that women constitute a very small proportion of the total number of directors on corporate boards. This is true not only in Australia, but for most countries across the globe. In 2012 the US organisation Catalyst published data for 44 countries that measured the number of women on corporate boards. It showed that the median percentage of women on corporate boards in US companies was approximately 8 per cent. ${ }^{106}$ The low level of women on corporate boards has been highlighted over the last 10 years as a problem that needs to be addressed. There are now political and regulatory trends worldwide promoting women in leadership. With the aim of replacing slow progress, many governments across the world have begun to develop action to promote and/or mandate increased female representation on corporate boards.

\footnotetext{
104 Peta Spender, 'Gender Diversity on Boards in Australia - Waiting for the Great Leap Forward?’ (2012) 27(1) Australian Journal of Corporate Law 22, 38.

105 Ibid 37.

106 Catalyst, 'Quick Takes: Women on Boards', (Report, Catalyst, 2012) <http://www.board agender.org/files/Catalyst-2012-Global-Women-on-Boards.pdf> .
} 
According to Klettner, Clarke, and Boersma, '[t]he issue of gender diversity in leadership has moved from being an issue of equality and sociology squarely into the realm of corporate governance' ${ }^{107}$ Women represent a large part, if not the majority, of the workforce in many industry sectors, and the underutilisation of their leadership potential is a matter of both equity and efficiency. The economic benefits that stem from gender equality are also cited.

The international debate regarding the relative benefits of quotas and targets in achieving gender diversity on boards has been hotly contested over the last decade. In major European countries mandatory quotas were adopted, while in Australia and other countries the voluntary setting of targets has been encouraged. Quotas secure substantial change through compliance, while targets may encourage change through strategic initiatives. Debates about women on boards have focused on measures designed to achieve equality of access, and across countries governmental approaches may be categorised as 'hard' or 'soft'. Hard strategies involve more coercive means of achieving equality of outcomes such as legislation for affirmative action and quotas. The soft strategies involve persuasion of market actors to achieve equality of access. The development of these strategies also involves stakeholder engagement which may be classified as coercive (for example, legislation for quotas); liberal (promoting voluntary actions by corporate actors); or collaborative (involving co-operation amongst stakeholders). ${ }^{108}$

To resolve the low level of female participation on boards, the two most discussed forms of regulatory intervention are the setting of gender targets or quotas. These can be imposed as mandatory by law, with sanctions if they are not achieved: for example, Norway's quota of 40 per cent women on boards. Alternatively, they can be softer in nature: for example the UK's recommendation of a target of 25 per cent women on boards which has raised expectations even though adoption is formally voluntary. Both of these methods have been effective at spurring an increase in numbers although it is still too early to judge the effectiveness of the UK's voluntary approach.

Further work by Klettner, Clarke and Boersma, on the strategic and regulatory approaches to increasing women in leadership, discusses in detail the regulatory solutions of quotas or targets. They note the 2009 CAMAC report, and the changes to the ASX Corporate Governance Council's amended $3^{\text {rd }}$ edition of the Corporate Governance Principles and Recommendations, requiring the

\footnotetext{
107 Alice Klettner, Thomas Clarke and Martijn Boersma, 'The Impact of Soft Law on Social Change: Measurable Objectives for Achieving Gender Diversity on Boards of Directors' (2013) 28 Australian Journal of Corporate Law 138, 140.

${ }^{108}$ Ibid 144.
} 
disclosure of diversity. ${ }^{109}$ The use of the 'comply or explain' technique, and the interaction of voluntary regulation with market expectations, has been quite effective and less costly than US-style prescriptive regulation. ${ }^{110}$ The measurable targets for ASX listed companies, compliance with which must be disclosed, is also having some direct influence. There is, however, no clear evidence as to which route is more effective for improving gender or other diversity factors on boards.

The researchers draw conclusions, with which the present author agrees to some degree. The Australian approach of encouraging change through organisationwide policy improvements and targets will, it is hoped, improve female representation along the length of the pipeline to leadership and not only at the top. However, widespread and significant changes in behaviour and practice will be required over a sustained period of time if this goal is to be achieved within an entirely voluntary targets regime. There must be a careful monitoring of progress, and a measuring of this progress against the performance of countries that have adopted quota regimes. ${ }^{111}$

\section{CONCLUSION}

It is without doubt time for change in many boardrooms around Australia, as well as in many other countries. There is less doubt now than there has ever been about the need for greater diversity in board composition, starting with gender. Age and ethnicity also need to be taken into account. The more vexing questions involve the choice between the introduction of mandated quotas, and the implementation of softer voluntary targets. If countries that have adopted quotas make more rapid progress in gender diversity in leadership there will, presumably, be insistent calls for the adoption of quotas in all jurisdictions. In the meantime, rather than quotas and targets being seen to be entirely different approaches, they can be seen to be mutually reinforcing. There is a wide spectrum of possible regulatory approaches. It will be interesting to see which of them prove most effective. Probably, time will tell how effective the new ASX Corporate Governance Principles on diversity will be. Also, successful companies which demonstrate the many benefits of having a diverse board of

\footnotetext{
${ }^{109}$ Australian Securities Exchange Corporate Governance Council, above n 6, Recommendation 1.5 .

${ }^{110}$ Alice Klettner, Thomas Clarke and Martijn Boersma, 'Strategic and Regulatory Approaches to Increasing Women in Leadership: Multilevel Targets and Mandatory Quotas as Levers for Cultural Change' (2014) Journal of Business Ethics (online) $13<$ http://www.vipsight. eu/images/jbe.pdf>.

${ }^{111}$ Klettner, Clarke and Boersma, above n 107, 165.
} 
directors will affect future developments. In looking to the future we should remember Winston Churchill's observation that 'however beautiful the strategy, you should occasionally look at the results'. ${ }^{112}$

112 The Churchill Centre, Winston Churchill for Traders \& Analysts: 25 Quotes Chosen to Motivate the Financial World (7 March 2013) <http://www.winstonchurchill.org/publications /chartwell-bulletin/bulletin-57-mar-2013/winston-churchill-for-traders-a-analysts>. 